\title{
Kondisi Potensi Wisata di Ekowisata Sungai Mudal Kabupaten Kulon Progo
}

\author{
Muhammad Irsyad* \\ Magister Kajian Pariwisata Sekolah Pascasarjana Universitas Gadjah Mada Yogyakarta, Indonesia \\ Email: irsyadmedsos@gmail.com
}

\begin{abstract}
This article basically has three objectives, knowing the tourism potential on Mudal River Ecotourism, knowing the stages and factors that influence tourism development and recommending tourism development efforts. To achieve these objectives the method used is descriptive qualitative by analyzing the data using weighting and scoring. The results of the study indicate that the existing tourism potential is amenity, accessibility, attractions and institutional support. The four potentials are in the 3rd phase including consolidation. The development effort that can be taken is to maximize land use without damaging the environment by taking into account the number of tourists; organize public transportation; planning management in the future; expand market segmentation and product diversification; improve the quality of human resources; actively involve local communities, align policy with the community and control the environment.
\end{abstract}

Keywords: Mudal River Ecotourism, tourism potential conditions and tourism development

\begin{abstract}
Abstrak
Artikel ini pada dasarnya mempunyai tiga tujuan, mengetahui potensi wisata di Ekowisata Sungai Mudal, mengetahui tahapan serta faktor-faktor yang mempengaruhi perkembangan pariwisata dan merekomendasikan upaya-upaya pengembangan pariwisata. Untuk mencapai tujuan tersebut metode yang digunakan adalah deskriptif kualitatif dangan analisis data menggunakan pembobotan dan skoring. Hasil penelitian menunjukkan bahwa potensi wisata yang ada adalah aksesbilitas, amenitas, atraksi dan dukungan kelembagaan. Empat potensi tersebut berada di fase ke-3 termasuk dalam kondisi konsolidasi. Upaya-upaya pengembangan yang dilakukan adalah memaksimalkan penggunaan lahan tanpa merusak lingkungan dan memperhitungkan jumlah wisatawan; menyelenggarakan transportasi umum; merencanakan pengelolaan di masa yang akan datang; memperluas segmentasi pasar dan diversifikasi produk; meningkatkan kualitas sumberdaya manusia; melibatkan masyarakat lokal secara aktif, keberpihakan kebijakan pada masyarakat dan pengendalian lingkungan.
\end{abstract}

Kata Kunci: Ekowisata Sungai Mudal, kondisi potensi wisata dan pengembangan pariwisata

\section{A. PENDAHULUAN}

Menikmati keindahan Indonesia dapat dilakukan melalui aktivitas seperti menjelajah alam, berinteraksi dengan masyarakat lokal dan memberikan kepeduliannya terhadap lingkungan sekitar. Aktivitas seperti ini yang dilakukan di alam dapat disebut sebagai ekowisata. Ekowisata adalah perjalanan terencana ke area alami untuk memahami budaya dan sejarah alam lingkungan, berhati - hati untuk tidak mengubah integritas ekosistem dan menghasilkan peluang ekonomi yang membuat konservasi sumber daya alam yang bermanfaat bagi masyarakat setempat (Epler Wood et al, 1991). Berdasarkan Laporan Kinerja Kementerian Pariwisata Tahun 2016 dalam portofolio produk wisata alam yang dimiliki oleh Indonesia sebesar 35\% yang didalamnya terdapat beberapa jenis wisata, seperti wisata bahari (marine tourism) 35\%, wisata ekologi (eco tourism) $45 \%$ dan wisata petualangan (adventure tourism) 20\%.

Kabupaten Kulon Progo yang merupakan salah satu wilayah dari lima Kabupaten/Kota di Provinsi Daerah Istimewa Yogyakarta memiliki berbagai macam produk wisata. Sebagian besar wilayah

\footnotetext{
* Corresponding author

Received: March 20, 2020; Revised: March 24, 2020; Accepted: March 28, 2020
} 
Kabupaten Kulon Progo merupakan perbukitan, yang dikenal sebagai "Menoreh Dome", berbentuk bulat lonjong dengan arah barat daya - timur laut (Suwarno, 2017). Produk wisata di daerah ini beranekaregam mulai dari wisata alam, wisata sejarah, wisata religi, wisata budaya hingga kuliner dan minat khusus lainnya. Pariwisata berbasis masyarakat di Kulon Progo dapat dikelompokkan menjadi wisata sosial budaya (sisi tengah dan selatan), wisata pertanian (sisi utara dan tengah), wisata alam dan lingkungan (sisi Perbukitan Menoreh dan Pantai Selatan) (Rahayu, 2016). Wisatawan di Desa Wisata Jatimulyo menginginkan paket wisata birdwatching dengan durasi wisata tidak lebih dari satu hari dan kesediaan membayar wisatawan Rp. 100.000 (Afif, 2018). Beranekaragam pilihan produk wisata yang bisa dinikmati oleh wisatawan menunjukkan peningkatan jumlah kunjungan wisatawan setiap tahunnya (Tabel 1).

Tabel 1. Jumlah Kunjungan Wisatawan di Kabupaten Kulon Progo

\begin{tabular}{ccccc}
\hline Wisatawan & $\mathbf{2 0 1 5}$ & $\mathbf{2 0 1 6}$ & $\mathbf{2 0 1 7}$ & $\mathbf{2 0 1 8}$ \\
\hline Mancanegara & 23 & 6.506 & 10.455 & 44.947 \\
\hline Nusantara & 1.289 .672 & 1.346 .894 & 1.390 .331 & 1.924 .676 \\
\hline
\end{tabular}

Sumber : Buku Statistik Kepariwisataan DIY, 2019

Hal ini menunjukkan peluang sektor pariwisata yang dimilki oleh Kabupaten Kulon Progo sangat besar. Jumlah kunjungan wisatawan di Daerah Istimewa Yogyakarta yang meningkat ke objek wisata menjadi salah satu indikator keberhasilan pengelola dalam mendatangkan wisatawan (Yulianto, 2017). Peluang ini dimanfaatkan oleh salah satu objek wisata di Desa Jatimulyo, Kecamatan Girimulyo yaitu Ekowisata Sungai Mudal (ESM).

Potensi wisata yang dimiliki oleh ESM berupa atraksi wisata atau daya tarik wisata, aksesbilitas dan amenitas. Tanpa daya tarik tidak akan ada kebutuhan untuk jasa pariwisata, dimana tidak akan ada pariwisata jika tidak ada daya tarik (Swarbrooke, 2002). ESM terletak di Dusun Banyunganti, Desa Jatimulyo, Kecamatan Girimulyo. Objek wisata ini memiliki atraksi wisata lahan untuk berkemah, taman bunga anggrek dan aliran sungai mulai dari mata air hingga air terjun dalam satu wilayah. Selain terdapat atraksi wisata ESM memiliki keunggulan pada amenitas, yaitu terdapat layanan wifi gratis bagi pengunjung. Fasilitas wifi ini merupakan bagian dari program CSR (Corporate Social Responsibility). Saat ini ESM dikelola dan dikembangkan oleh masyarakat sekitar dengan dukungan BUMN PT. PLN melalui dana CSR.

Pengembangan ESM memberikan peran penting bagi pemerintah daerah dan masyarakat setempat dalam pengelolaan, dan pelestarian lingkungan. Pengembangan pariwisata di salah satu objek wisata harus didukung oleh atraksi, pelayanan, akomodasi, transportasi, informasi, promosi dan kelembagaan. Komponen yang membentuk suatu produk wisata diantaranya adalah daya tarik atau atraksi, amenitas, dan aksesibilitas (Inskeep, 1991). Masyarakat sebagai bagian dari objek wisata harus memiliki peran aktif dalam proses pengembangan dan pemerintah harus memberikan kesempatan bagi masyarakat lokal untuk berperan melalui kebijakan yang berpihak. Keberlanjutan objek wisata memerlukan model dalam meningkatkan berbagi unsur didalamnya termasuk pelibatan masyarakat lokal (Hanggraito \& Irsyad, 2019).

Sebagai objek wisata, ESM memiliki potensi wisata yang sangat berpotensi untuk dikembangkan lebih jauh lagi. Kenyataannya objek wisata yang tergolong masih baru dikelola secara kelembagaan pada tahun 2015. Objek wisata dengan peran aktif masyarakat yang didukung pendanaan CSR dari PT. PLN telah didukung komponen atraksi, aksesbilitas dan amenitas. Keberhasilan implementasi strategi destinasi wisata didukung dengan adanya dukungan finansial, sarana prasarana, dan kelembagaan dalam melaksanakan program dan kegiatan (Irsyad, 2017). Oleh karena itu perlu dilakukan upaya 
pengembangan dengan pemanfaatan potensi alam, strategi pengelolaan, dukungan kelembagaan, kebijakan nasional maupun daerah dan peluang pasar yang ada.

Dari pendahuluan tersebut maka perlu dilakukan identifikasi terhadap potensi - potensi yang dapat dikembangkan, mengetahui tahapan serta faktor - faktor yang mempengaruhi perkembangan objek wisata dan merekomendasikan upaya - upaya pengembangan ESM.

\section{B. METODE PENELITIAN}

Penelitain menggunakan pendekatan deskriptif kualitatif. Pengumpulan data diperoleh melalui observasi lapangan, wawancara mendalam, dan data sekunder yang terdiri dari jumlah kunjungan wisatawan dan dokumen pengelolaan. Wawancara mendalam dilakukan kepada pengelola inti Esm yang terdiri dari ketua, sekretaris, bendahara, dan koordinatoar masing-masing bidang. Analisis dilakukan terhadap potensi pariwisata di ESM. Hal ini dilakukan untuk mengetahui kondisi potensi - potensi yang dapat dikembangkan dan faktor - faktor yang mendukung pengembangan tersebut sehingga dapat dirumuskan pengembangan lebih lanjut.

Penilaian dilakukan terhadap aspek - aspek objek wisata, transportasi, wisatawan dukungan kelembagaan dan lingkungan melalui parameter seperti akomodasi, fasilitas, pelayanan, wisatawan, promosi, daya dukung kawasan, atraksi, kelembagaan, sumberdaya manusia dan lingkungan. Untuk mengetahui parameter potensi pengembangan sangat relatif, menggunakan 7 parameter. Hal ini diakrenakan parameter yang ditemukan dilapangan tidak sesuai dengan parameter yang menjadi acuan. Penilaian ini berdasarkan modifikasi beberapa sumber pengembangan pariwisata diantaranya adalah Model Miossec's dan Model Butler's.

Penilaian potensi yang berkembang di ESM dilakukan dengan pengharkatan (Scoring) dan pembobotan (weighting) menggunakan skala 1 - 3. Data primer dan data sekunder dianalisis secara deskriptif kualitatif. Setelah dilakukan pengharkatan (scoring) dan pembobotan (weighting), hasilnya dapat dibuat kelas interval atau Rentang Skala (RS) yang menunjukkan fase 0, fasi 1, fase 2, fase 3 dan fase 4. Nilai interval masing - masing fase diperoleh dari total nilai skor tertinggi dikurangi total nilai skor terendah, hasilnya dibagi dengan jumlah fase. Untuk menjelaskan kategori dan skor penilaian maka digunkan rumus untuk mencari RS (Husein, 2003).

Parameter yang digunakan dalam pengembangan terdiri dari 4 jenis, amenitas, aksesbilitas, atraksi dan dukungan kelembagaan. Aspek amenitas terdiri dari akomodasi, rumah makan, fasilitas informasi, sumber air bersih, fasilitas penunjang, fasilitas kebersihan dan lokasi parkir kendaraan. Aspek aksesbilitas terdiri dari jangkauan pasar, media promosi, jumlah kunjungan, perjalanan wisata, daya tampung kawasan, keragaman atraksi wisata dan kondisi objek wisata. Aspek atraksi terdiri dari moda transportasi, pencapaian lokasi, lokasi objek, kondisi jalan, jaringan transportasi, waktu tempuh dan jumlah jaringan transportasi. Aspek dukungan kelembagaan terdiri dari peran masyarakat, peran pemerintah, peran swasta, pendanaan, sumberdaya manusia, daya dukung lingkungan dan pengelolaan.

\section{HASIL DAN ANALISIS}

ESM merupakan objek wisata alam dengan atraksi utamanya adalah sungai. Terbentuknya aliran sungai berasal dari mata air dengan volume cukup besar yang keluar dari dalam gua. Lokasi aliran sungai yang membentuk tangga dengan tingkatan yang berbeda terdapat kolam dengan air berwarna hijau dan jernih. Aktivitas wisatawan yang bisa dilakukan di ESM adalah berendam di kolam pemandian, menikmati taman dengan Bunga Anggrek di sekelilingnya, berfoto di jembatan bambu, berkemah di lokasi camping ground, bermain flaying fox dan outbond. 
Lokasi dapat ditempuh dari pusat Kota Yogyakarta menggunakan kendaraan bermotor selama \pm 1 jam dengan jarak yang ditempuh $\pm 30 \mathrm{~km}$. Tidak ada transportasi umum yang melewati atau dengan tujuan ESM. Kondisi jalan beraspal dengan kontur jalan menanjak dan menurun sudah dapat dilalui kendaraan roda empat dan roda dua. Jenis kendaraan yang dapat melewati jalur ini berupa motor, mobil dan bus kecil. Akses jalan dapat dilalui dari dua arah, yaitu utara melewati Jalan Raya Kaligesing dan dari selatan melewati Jalan Sermo - Girimulyo. Terdapat penunjuk arah menuju lokasi ESM jika wisatawan telah sampai di objek wisata Goa Kiskendo.

Fasilitas yang menunjang aktivitas wisatawan dalam bentuk pelayanan. Fasilitas tersebut diantaranya adalah akses wifi gratis, toilet, Mushola, penyewaan ban pelampung, loker penitipan barang, gazebo, jembatan dari bambu, air minum grratis, tempat sampah, kotak P3K dan area parkir. Fasilitas ini merupakan hasil dukungan dari dana CSR yang diberikan PT. PLN. Sekitar kawasan ESM terdapat beberapa lokasi yang fungsinya adalah untuk tinggal sementara waktu. Terdapat homestay, penginapan melati, rumah joglo yang disediakan untuk wisatawan yang berkelompok dan penyewaan tenda.

Pelayanan bagi wisatawan berupa penyediaan makanan dan minuman di warung - warung yang ada di dalam objek wisata dan sekitar objek wisata berupa rumah makan dan cafe. Cinderamata yang dijual di dalam objek wisata berupa kaos dengan gambar dan tulisan Sungai Mudal. Jika membutuhkan informasi, wisatawan bisa ke loket yang berfungsi juga sebagai pusat informasi. Pengelola yang berjaga di sekitar kolam untuk memberikan keamanan bagi wisatawan. Jika memang terjadi hal yang tidak diingankan pengelola siap memberikan pertolongan pertama dan jika semakin parah akan diantarkan menuju Puskesmas terdekat.

Sejak dikelolanya ESM secara profesional pada tahun 2015 maka objek wisata ini telah dikunjungi wisatawan dari dalam dan luar Kabupaten Kulon Progo. Jumlah kunjungan wisatawan yang meningkat dari tahun 2015 - 2017 dapat dilihat pada (Tabel 2 ).

Tabel 2. Jumlah Kunjungan Wisatawan di ESM

\begin{tabular}{ccccc}
\hline & $\mathbf{2 0 1 5}$ & $\mathbf{2 0 1 6}$ & $\mathbf{2 0 1 7}$ & $\mathbf{2 0 1 8}$ \\
\hline Wisatawan & 8330 & 11205 & 13022 & 54965 \\
\hline
\end{tabular}

Sumber : Pengelola Ekowisata Sungai Mudal, 2018

ESM dikelola oleh masyarakat di sekitar objek wisata dalam bentuk Kelompok Sadar Wisata (Pokdarwis). Pada awalnya merupakan inisiatif masyarakat sekitar untuk membersihkan pinggiran Sungai Mudal setiap minggunya secara gotong royong. Dukungan pengembangan objek wisata ini diberikan oleh PT. PLN melalui Dana CSR yang dikelola langsung oleh pengelola ESM dalam bentuk pembangunan amenitas. PT PLN juga memberikan bantuan berupa pembangkit tenaga listrik Pico Hydro yang memberikan pasokan listrik di objek wisata. Harga tiket masuk wisatawan dikenakan biaya Rp 6.000, untuk parkir kendaraan roda dua Rp 2.000 dan kendaraan roda empat Rp 5.000.

\section{Kondisi Amenitas}

Akomodasi di sekitar ESM yang tersedia berupa homestay, penginapan dan camping ground yang tendanya disediakan oleh pengelola. Rumah makan tersedia berupa warung, rumah makan dan cafe. Fasilitas informasi yang dimiliki ESM tempatnya menjadi satu dengan penjualan tiket. Sumber air bersih Sungai Mudal berada satu lokasi dengan ESM. Fasilitas penunjang yang bisa dirasakan oleh wisatawan berupa penitipan barang, wifi gratis, kotak $\mathrm{P} 3 \mathrm{~K}$ telah tersedia, akan tetapi perlu ditingkatkan lagi seperti koneksi wifi yang sering mati dan kesiapan petugas dalam menjaga keselamatan wisatawan. Toilet dan tempat sampah telah tersedia, perlu ditingkatkan lagi seperti pemisahan sampah organik dan non 
organik dan kebersihan toilet selalu dijaga. Lokasi parkir belum seluruhnya memiliki atap sehingga kendaraan sebagian wisatawan masih terkena langsung sinar matahari.

Setelah diketahui kondisi amenitas di ESM, maka dilakukan penilaian untuk mengetahui jumlah skor (Tabel 3). Hasil perhitungan Rentang Skala (RS) diperoleh angka 11 sehingga kisaran harkat berdasarkan fase pengembangan dapat dilihat pada tabel berikut ini (Tabel 4).

Jumlah skor diperoleh dari hasil perkalian antara bobot dan harkat masing - masing parameter yang dinilai diperoleh angka 42. Jumlah skor 42 berada dikisaran harkat 39 - 50 maka pengembangan pariwisata di ESM berdasarkan aspek amenitas berada di fase 3 yaitu pengaruh ESM terhadap pengembangan dan pembangunan fisik di sekitarnya.

\section{Kondisi Aksesbilitas}

Wisatawan dapat menggunakan moda transportasi roda dua dan roda empat, jenis kendaraannya berupa motor, mobil dan bus kecil. Waktu yang dibutuhkan menuju lokasi dari pusat Kota Yogyakarta \pm 1 jam. Berada di jalan yang menghubungkan Kabupaten Kulon Progo dan Kabupaten Purworejo. Kondisi jalan yang dilalui menanjak dengan kondisi aspal yang baik dapat dilalui kendaraan roda dua dan roda empat. Tidak ada transportasi menuju dan melewati ESM, hanya dapat dijangkau dengan kendaraan pribadi. Jalan yang menanjak dengan kondisi aspal yang baik dapat dilewati kendaraan dengan kecepatan sedang minimal $20 \mathrm{~km} / \mathrm{jam}$. Ruas jalan dua arah dapat dilalui kendaraan roda dua dan roda empat.

Setelah diketahui kondisi aksesbilitas di ESM, maka dilakukan penilaian untuk mengetahu jumlah skor (Tabel 3). Hasil perhitungan Rentang Skala (RS) diperoleh angka 11 sehingga kisaran harkat berdasarkan fase pengembangan dapat dilihat pada tabel berikut ini (Tabel 4).

Jumlah skor diperoleh dari hasil perkalian antara bobot dan harkat masing - masing parameter yang dinilai diperoleh angka 43. Jumlah skor 43 berada dikisaran harkat 39 - 50 maka pengembangan pariwisata di ESM berdasarkan aspek aksesbilitas berada di fase 3 yaitu mulai tersusun rute perjalanan wisata.

\section{Kondisi atraksi}

Wisatawan yang berkunjung ke ESM sebagian besar berasal dari Indonesia, dengan kecenderungan berasal dari DIY. Media yang digunakan berupa media digital pada instagram dan media cetak berupa brosur. Jumlah kunjungan wisatawan dapat dilihat pada (Tabel 2). Biro perjalanan wisatawa yang mendatangkan wisatawan ke ESM masih dalam jangkauan nasional. Pada saat puncak kunjungan wisatawan atau saat musim liburan, ESM masih bisa menampung wisatawan dalam jumlah yang banyak. Wisatawan dapat melakukan aktivitas berendam di kolam, bermain flaying fox, menikmati taman bunga anggrek, susur air terjun, out bond dan atraksi wisata lainnya. Lokasi ESM masih alami dengan kondisi sungai masih seperti aslinya.

Setelah diketahui kondisi atraksi di ESM, maka dilakukan penilaian untuk mengetahu jumlah skor (Tabel 3). Hasil perhitungan Rentang Skala (RS) diperoleh angka 11 sehingga kisaran harkat berdasarkan fase pengembangan dapat dilihat pada tabel berikut ini (Tabel 4).

Jumlah skor diperoleh dari hasil perkalian antara bobot dan harkat masing - masing parameter yang dinilai diperoleh angka 42. Jumlah skor 42 berada dikisaran harkat 39 - 50 maka pengembangan pariwisata di ESM berdasarkan aspek atraksi berada di fase 3 yaitu muncul persaingan dengan objek wisata sekitar.

\section{Kondisi Dukungan Kelembagaan}

Pengelolaan yang dilakukan di ESM Masyarakat terlibat secara langsung dalam perencanaan, pelaksanaan dan pengawasan. masyarakat mengambil bagian dalam bentuk pengelolan, penyedia 
akomodasi, pemilik rumah makan, dll. Pengelola sudah merasakan peran dari pemerintah seperti pelatihan dasar kepariwisataan dan dukungan fisik lainnya seperti kemudahan aksesbilitas melalui pembangunan jalan. Selain itu didukung juga oleh dana CSR PT. PLN membuat pengelola semakin mudah mengembangkan ESM karena kebutuhan seperti fasilitas penunjang wisatawan telah tersedia. Pemasukan yang dihasilkan dari penjual tiket masuk digunakan untuk membayar tenaga dan pikiran yang dikeluarkan oleh pengelola dan disishkan dalam bentuk kas untuk pengembangan. Pengelola dan masyarakat sekitar telah mendapatkan pelatihan berupa pengetahuan dasar keparaiwisatan dan penmbuatan produk lokal seperti gula semut. Pembatasan jumlah wisatawan yang berkunjng belum dilakukan. Aspek - aspek ekowisata dalam pengelolaan sudah dilakukan tapi perlu ditingkatkan.

Setelah diketahui kondisi dukungan kelembagaan di ESM, maka dilakukan penilaian untuk mengetahu jumlah skor (Tabel 3). Hasil perhitungan Rentang Skala (RS) diperoleh angka 11 sehingga kisaran harkat berdasarkan fase pengembangan dapat dilihat pada tabel berikut ini (Tabel 4).

Jumlah skor diperoleh dari hasil perkalian antara bobot dan harkat masing - masing parameter yang dinilai diperoleh angka 43. Jumlah skor 43 berada dikisaran harkat 39 - 50 maka pengembangan pariwisata di ESM berdasarkan aspek dukungan kelembagaan berada di fase 3 yaitu bertambahnya jaringan transportasi merubah sikap penerimaan wisatawan dan aktivitas wisata oleh masyarakat lokal.

Hasil analisa potensi wisata ESM diketahui bahwa kondisinya berada di fase yang ke-3 yaitu dalam kondisi konsolidasi. Pada fase ini jumlah total wisatawan akan meningkat bahkan melebihi jumlah masyarakat di sekitarnya, pemasaran dan periklanan akan luas jangkauannya, pertumbuhan pada industri pariwisata di sekitarnya, tersedianya fasilitas secara lengkap dan dengan sendirinya masyarakat lokal akan terlibat dalam industri pariwisata (Butler, 1980). Pada fase pengembangan ke-3 ESM memiliki kondisi, keberhasilan objek wisata mempengaruhi pengembangan dan pembangunan fisik di sekitar objek wisata, mulai tersusun rute perjalanan wisata, muncul persaingan dengan objek wisata sekitar dan lebijakan pemerintah dan dukungan pihak ke tiga mempengaruhi sikap penerimaan wisatawan dan aktivitas wisata oleh masyarakat lokal.

\section{Pengembangan Ekowisata Sungai Mudal}

Pengembangan potensi pada aspek amenitas yang dapat dilakukan adalah merawat sarana dan prasarana yang telah tersedia, mengelola sampah dan limbah, menggunakan bahan - bahan yang ramah lingkungan, meningkatkan pelayanan pada jasa akomodasi yang telah tersedia dan lokasi dan bangunan khusus untuk memberikan informasi kepada wisatawan. Pengembangan yang akan dilakukan didukung dengan dana CSR yang diberikan oleh PT. PLN dan kondisi kunjungan wisatawan yang meningkat setiap tahunnya. Kelemahan terpenting dari pengembangan ekowisata adalah masalah pembuangan limbah, kurangnya pengelolaan limbah, pembangunan fasilitas wisata yang tidak terkontrol dan disintegrasi struktur sosial dan budaya masyarakat setempat (Rica, 2009). Hambatan yang akan terjadi dalam pengembangan adalah pengetahuan pengelola terkait pengelolaan sampah dan limbah. Hal yang perlu diperhatikan dalam pengembangana aspek ini adalah lahan yang terbatas dapat dimaksimalan tanpa merusak lingkungan dan memperhitungkan jumlah wisatawan yang berkunjung.

Aspek aksesbilitas untuk pengembangan dapat melakukan penyelenggaraan moda transportasi yang melewati atau menghubungkan objek wisata di sekitar ESM dan informasi yang jelas mengenai aksesbilitas dapat tersampaikan ke calon pengunjung. Kondisi jalan yang bagus telah dapat dilalui oleh kendaraan roda empat menjadi aspek yang mendukung dalam pengembangan. Akan tetapi aspek yang menghambatnya adalah dana untuk pengadaan moda transportasi cukup besar dan tidak dapat dilakukan hanya satu lembaga. Kondisi geografis di sekitar ESM termasuk dalam kawasan Perbukitan Menoreh dengak kontur lahan yang menanjak dan menurun harus menjadi faktor utama dalam merencanakan pengembangan aspek ini. Kelayakan ekowisata tidak hanya bergantung pada keindahan 
alam, akan tetapi juga pada aksesibilitas kawasan, pelayanan yang tersedia, keamanan wisatawan, ketersediaan amenitas, dan keterjangkauan harga (Hearne \& Santos, 2005).

Aktivitas wisatawan untuk berinteraksi dengan lingkungan dan menambah wawasan terkait Sungai Mudal, menjaga kebersihan lingkungan, penyelenggaraan event secara rutin, mengelola media promosi lebih interaktif melakukan pembatasan pengunjung dan menjalin kerjasama dengan BPW untuk mendatangkan wisatawan ke ESM merupakan pilihan - pilihan untuk mengembangkan aspek atraksi. Didukung dengan kondisi ESM masih alami dan berada di sumber air Sungai Mudal dan pengelola telah memiliki tupoksi di masing - masing seksi. Hambatan yang akan dilalui dalam pengembangan adalah kemampuan pengelola masih terbatas dan perlu pihak ke-3 untuk memberikan pelatihan dan menjadi penghubung ke pihak - pihak lainnya. Ekowisata tanpa adanya perencanaan atau intervensi formal menjadikan masyarakat lokal tidak mendapatkan manfaat, kurangnya kesadaran, dan merantau keluar daerah (Campbell, 1999). Hal - hal yang perlu diperhatikan dalam pengembangan adalah perencanaan pengelolaan yang tepat, memperluas segmentasi pasar, dan diversifikasi produk. Keberhasilan ekowisata adalah integritas lingkungan dan budaya yang dijalankan melalui aspek sosial, ekonomi, dan politik tertentu (Cater, 2015; Coria \& Calfucura, 2012; Rica, 2009).

Pengembangan aspek dukungan kelembagaan yang dapat dilakukan adalah sertifikasi kompetensi bidang pemandu wisata dan operator out bond, pengembangan produk lokal melalui standarisasi produk dan membuat rencana pengelolaan secara berskala. Ekowisata dapat diterapkan dalam konteks negara berkembang karena menekankan pentingnya komunitas lokal memiliki kontrol dan manfaat dari inisiatif ekowisata di daerah mereka (Scheyvens, 1999). Aspek ini didukung oleh program - program yang dilakukan oleh lembaga terkait seperti Pemerintah Daerah atau Kementerian Pariwisata. Mendorong partisipasi masyarakat lokal dalam pengembangan ekwoisata dilakukan dengan pendekatan pemberdayaan masyarakat, dukungan program pemerintah, dan keuntungan secara ekonomi (Lai, 2006). Ekowisata yang dikelola masyarakat lokal akan menghasilkan konservasi sumber daya alam tetapi juga dalam peningkatan pembangunan (Coria \& Calfucura, 2012). Penghambat yang bisa terjadi dalam pengembangan adalah kemitraan lintas sektoral. Hal yang perlu diperhatikan dalam pengembangan aspek dukungan kelembagaan adalah meningkatkan kualitas SDM pengelola, melibatkan masyarakat lokal secara aktif, keberpihakan kebijakan pada masyarakat, dan pengendalian lingkungan.

Tabel 3. Penilaian Potensi Pengembangan

\begin{tabular}{|c|c|c|c|c|c|}
\hline Aspek & No & Parameter & Bobot & Harkat & Skor \\
\hline \multirow{10}{*}{ Amenitas } & 1 & Akomodasi/Penginapan di Sekitar Objek Wisata & 3 & 3 & 9 \\
\hline & 2 & Rumah Makan/Restoran di Sekitar Objek Wisata & 3 & 3 & 9 \\
\hline & 3 & Fasilitas Informasi & 3 & 2 & 6 \\
\hline & 4 & Sumber Air Bersih & 2 & 3 & 6 \\
\hline & 5 & Fasilitas Penunjang & 2 & 2 & 4 \\
\hline & 6 & Fasilitas Kebersihan & 2 & 2 & 4 \\
\hline & 7 & Lokasi Parkir Kendaraan & 2 & 2 & 4 \\
\hline & & Jumlah & & & 42 \\
\hline & 1 & Moda Transportasi & 3 & 2 & 6 \\
\hline & 2 & Pencapaian Lokasi & 3 & 3 & 9 \\
\hline
\end{tabular}




\begin{tabular}{|c|c|c|c|c|c|}
\hline \multirow{6}{*}{ Aksesibilitas } & 3 & Lokasi Objek & 3 & 3 & 9 \\
\hline & 4 & Kondisi Jalan & 2 & 3 & 6 \\
\hline & 5 & Jaringan Transportasi & 2 & 1 & 2 \\
\hline & 6 & Waktu Tempuh & 2 & 2 & 4 \\
\hline & 7 & Jumlah Jaringan Transportasi & 2 & 2 & 4 \\
\hline & & Jumlah & & & 40 \\
\hline \multirow{8}{*}{ Atraksi } & 1 & Jangkauan Pasar & 2 & 2 & 4 \\
\hline & 2 & Media Promosi & 2 & 2 & 4 \\
\hline & 3 & Jumlah Kunjungan & 3 & 2 & 6 \\
\hline & 4 & Perjalanan Wisata & 2 & 2 & 4 \\
\hline & 5 & Daya Tampung Kawasan & 3 & 2 & 6 \\
\hline & 6 & Keragaman Atraksi Wisata & 3 & 3 & 9 \\
\hline & 7 & Kondisi Objek Wisata & 3 & 3 & 9 \\
\hline & & Jumlah & & & 42 \\
\hline \multirow{8}{*}{$\begin{array}{l}\text { Dukungan } \\
\text { Kelembagaan }\end{array}$} & 1 & Peran Masyarakat & 3 & 3 & 9 \\
\hline & 2 & Peran Pemerintah & 3 & 3 & 9 \\
\hline & 3 & Peran Swasta & 3 & 3 & 9 \\
\hline & 4 & Pendanaan & 2 & 3 & 6 \\
\hline & 5 & Sumberdaya Manusia & 2 & 2 & 4 \\
\hline & 6 & Daya Dukung Lingkungan & 2 & 1 & 2 \\
\hline & 7 & Pengelolaan & 2 & 2 & 4 \\
\hline & & Jumlah & & & 43 \\
\hline
\end{tabular}

Sumber: Olahan Penulis, 2020

Tabel 4. Penilaian Fase Potensi Pengembangan

\begin{tabular}{|c|c|c|c|}
\hline Aspek & Fase & Kisaran Harkat & Keterangan \\
\hline \multirow{5}{*}{ Amenitas } & 0 & $3-14$ & $\begin{array}{l}\text { Objek wisata belum melakukan pembangunan/tersentuh } \\
\text { pembangunan }\end{array}$ \\
\hline & 1 & $15-26$ & Mulai ada pembangunan objek wisata \\
\hline & 2 & $27-38$ & Mulai terorganisir dan ada pengelolaan \\
\hline & 3 & $39-50$ & $\begin{array}{l}\text { Keberhasilan objek wisata mempengaruhi } \\
\text { pengembangan dan pembangunan fisik di sekitar objek } \\
\text { wisata }\end{array}$ \\
\hline & 4 & $51-62$ & Mulai menetapkan perencanaan dalam pembangunan \\
\hline \multirow[b]{3}{*}{ Aksesibilitas } & 0 & $3-14$ & Objek wisata masih terisolir/belum terjangkau \\
\hline & 1 & $15-26$ & Mulai dibuka jaringan aksesbilitas \\
\hline & 2 & $27-38$ & $\begin{array}{l}\text { Bertambahnya } \quad \text { jaringan } \\
\text { menghubungkan antar wilayah }\end{array}$ \\
\hline
\end{tabular}




\begin{tabular}{|c|c|c|c|}
\hline & 3 & $39-50$ & Mulai tersusun rute perjalanan wisata \\
\hline & 4 & $51-62$ & $\begin{array}{l}\text { Bertambahnya jaringan transportasi merubah sikap } \\
\text { dalam menerima wisatawan oleh masyarakat lokal }\end{array}$ \\
\hline \multirow{5}{*}{ Atraksi } & 0 & $3-14$ & Belum adanya informasi yang jelas tentang objek wisata \\
\hline & 1 & $15-26$ & Objek wisata mulai dikenal \\
\hline & 2 & $27-38$ & $\begin{array}{l}\text { Meningkatnya citra objek wisata dan makin dikenal } \\
\text { wisatawan }\end{array}$ \\
\hline & 3 & $39-50$ & Muncul persaingan dengan objek wisata sekitar \\
\hline & 4 & $51-62$ & $\begin{array}{l}\text { Ada kontrol perencanaan dan penlokan pariwisata dari } \\
\text { masyarakat lokal }\end{array}$ \\
\hline \multirow{5}{*}{$\begin{array}{l}\text { Dukungan } \\
\text { Kelembagaan }\end{array}$} & 0 & $3-14$ & $\begin{array}{l}\text { Masyarakat lokal masih terbatas pengetahuan terkait } \\
\text { pariwisata, kebijakan pemerintah masih terbatas, tidak } \\
\text { ada dukungan dari pihak ke tiga. }\end{array}$ \\
\hline & 1 & $15-26$ & $\begin{array}{l}\text { Kebijakan pemerintah, tanggapan masyarakat dan } \\
\text { dukungan pihak ke tiga masih terbatas }\end{array}$ \\
\hline & 2 & $27-38$ & $\begin{array}{l}\text { Kebijakan pemerintah di aspek infrastruktur, masyarakat } \\
\text { lokal mulai menerima kehadiran wisatawan dan pihak ke } \\
\text { ke tiga mulai melakukan dukungan. }\end{array}$ \\
\hline & 3 & $39-50$ & $\begin{array}{l}\text { Kebijakan pemerintah dan dukungan pihak ke tiga } \\
\text { mempengaruhi sikap penerimaan wisatawan dan } \\
\text { aktivitas wisata oleh masyarakat lokal }\end{array}$ \\
\hline & 4 & $51-62$ & $\begin{array}{l}\text { Terdapat unsur penolakan pariwisata oleh masyarakat } \\
\text { lokal, kawasan telah sesaui kapasitas daya dukung }\end{array}$ \\
\hline
\end{tabular}

\section{Sumber: Diolah dari Model Miossec's (1976) dan Model Butler’s dalam Pearce (1989)}

\section{SIMPULAN}

Empat potensi yang digunakana dalam pengembangan Ekowisata Sungai Mudala (ESM), yaitu amenitas, aksesbilitas, atraksi dan dukungan kelembagaan. Amenitas dengan faktor - faktor yang mempengaruhi, seperti akomodasi, rumah makan, fasilitas Informasi, sumber air bersih, fasilitas penunjang, fasilitas kebersihan dan lokasi parkir kendaraan. Aksesbilitas dengan faktor - faktor yang mempengaruhi, seperti moda transportasi, pencapaian lokasi, lokasi objek, kondisi jalan, jaringan transportasi, waktu tempuh dan jumlah jaringan transportasi. Atraksi dengan faktor - faktor yang mempengaruhi, seperti jangkauan pasar, media promosi, jumlah kunjungan, perjalanan wisata, daya tampung kawasan, keragaman atraksi wisata dan kondisi objek wisata. Dukungan kelembagaan dengan faktor - faktor yang mempengaruhi, seperti peran masyarakat, peran pemerintah, peran swasta, pendanaan, sumberdaya manusia, daya dukung lingkungan dan pengelolaan.

Pengembangan pariwisata menggunakan Miossec's model of tourism development dan evolusi pengenbangan pariwisata Model Butler's. Model Miossec's dan Model Butler's dari empat potensi tersebut berada di fase 3 termasuk dalam kondisi konsolidasi. Fase ke-3 dengan kondisi sebagai berikut, keberhasilan objek wisata mempengaruhi pengembangan dan pembangunan fisik di sekitar objek 
wisata, mulai tersusun rute perjalanan wisata, muncul persaingan dengan objek wisata sekitar dan kebijakan pemerintah dan dukungan pihak ke tiga mempengaruhi sikap penerimaan wisatawan dan aktivitas wisata oleh masyarakat lokal.

Upaya - upaya pengembangan yang dilakukan adalah memaksimalkan penggunaan lahan tanpa merusak lingkungan dan memperhitungkan jumlah wisatawan; menyelenggarakan transportasi umum; merencanakan pengelolaan; memperluas segmentasi pasar dan diversifikasi produk; meningkatkan kualitas sumberdaya manusia; melibatkan masyarakat lokal secara aktif, keberpihakan kebijakan pada masyarakat dan pengendalian lingkungan.

\section{DAFTAR REFERENSI}

Afif, F. (2018). Potensi birdwatching sebagai salah satu daya tarik wisata di desa wisata jatimulyo, kecamatan girimulyo,kabupaten kulon progo. Jurnal Media WIsata, 16(2), 1007-1015.

Buku Statistik Kepariwisataan DIY 2018

Butler, R.E. (1980). The Concept of a Tourist Area Cycle of Evolution: Implication for Managemenet of Resources. Canadian Georapher

Campbell, L. M. (1999). ECOTOURISM IN RURAL DEVELOPING COMMUNITIES, 26(3), 534-553.

Cater, C. (2015). Ecotourism, 6, 4165-4168. https://doi.org/10.1016/B978-0-08-0970868.91071-7

Coria, J., \& Calfucura, E. (2012). Ecotourism and the development of indigenous communities : The good, the bad, and the ugly. Ecological Economics, 73, 47-55. https://doi.org/10.1016/j.ecolecon.2011.10.024

Epler Wood, M., Gatz, F., \& Lindberg, K. (1991). The Ecotourism Society: An action agenda. In: J. Kusler (Ed.), Ecotourism and resource conservation (pp. 75-79). Selected papers from the 2nd International Symposium: Ecotourism and Resource Conservation, Madison: Omnipress

Hanggraito, Ahmadintya Anggit dan Irsyad, Muhammad. (2019). OPTIMALISASI SISTEM PARIWISATA DALAM MODEL PENGEMBANGAN DESA WISATA BERKELANJUTAN : STUDI KASUS DI DESA NEW NGLEPEN KABUPATEN SLEMAN, DI YOGYAKARTA. PROSIDING SEMINAR NASIONAL PENGABDIAN KEPADA MASYARAKAT, 11-20.

Hearne, R. R., \& Santos, C. A. (2005). TOURISTS' AND LOCALS ' PREFERENCES TOWARD ECOTOURISM DEVELOPMENT IN THE MAYA BIOSPHERE RESERVE , GUATEMALA, 303318. https://doi.org/10.1007/s10668-004-2944-3

Husein, Umar. (1999). Sumberdaya Manusia Dalam Organisasi. Jakarta: Gramedia

Inskeep, E. (1991). Tourism Planning An Integreted and Sustainable Development Approach. New York: Van Nostrand Reinhold

Irsyad, M. (2017). IMPLEMENTASI STRATEGI PENGEMBANGAN WISATA KEBUN BINATANG SURABAYA SEBAGAI DESTINASI WISATA DI KOTA SURABAYA. Jurnal Administrasi Bisnis (JAB, 42(2), 59-66.

Lai, P. (2006). Local perspectives of ecotourism development in Tawushan Nature Reserve, Taiwan, 27, 1117-1129. https://doi.org/10.1016/j.tourman.2005.11.010

Laporan Kinerja Kementeria Pariwisata Tahun 2016

Pearce, Douglas. (1989). Tourist Development, Second Edition. New Zealand: Senior Lecture in Geography University of Cantenbury

Rahayu. (2016). PENGEMBANGAN COMMUNITY BASED TOURISM SEBAGAI STRATEGI PEMBERDAYAAN EKONOMI MASYARAKAT DI KABUPATEN KULON PROGO, DAERAH ISTIMEWA YOGYAKARTATitle. Jurnal Penelitian Humaniora, 21(1), 1-13.

Rica, C. (2009). Ecotourism as a development strategy: experiences, 1225-1237. https://doi.org/10.1007/s10668-009-9214-3

Scheyvens, R. (1999). Ecotourism and the empowerment of local communities, 20, 245-249. 
Suwarno, Y. (2017). ANALISIS POTENSI WILAYAH KABUPATEN KULON PROGO PROVINSI DAERAH ISTIMEWA YOGYAKARTA DARI EKSTRAKSI PETA GEOLOGI. Prosiding Seminar Nasional Geografi UMS 2017, 663-670.

Swarbrooke, J. (2002). The Development \& Management of Visitor Attractions, 2nd edn. Butterworth Heinemann: Oxford UK

Yulianto, A. (2017). Analisis Objek Daya Tarik Wisata Favorit Berdasarkan Jumlah Pengunjung di Daerah Istimewa Yogyakarta. Jurnal Media WIsata, 15(2), 555-567. 